I N S T I T U T O

DE

M E D I C I N A

T R O P I C A L

DE

S ÃO PAULO

JOURNAL OF THE SÃO PAULO INSTITUTE OF TROPICAL MEDICINE

Universidade de São Paulo, Faculdade de Medicina, Departamento de Pediatria, Instituto de Tratamento do Câncer Infantil (ITACI), São Paulo, São Paulo, Brazil

Correspondence to: Silvana Forsait. Universidade de São Paulo, Faculdade de Medicina Departamento de Pediatria, Instituto de Tratamento do Câncer Infantil (ITACI), R. Galeno de Almeida, 148, CEP 05410-30, São Paulo, SP, Brazil

Tel: +55 11 3897-3807

E-mail: silforsait@gmail.com

Received: 30 July 2016

Accepted: 14 February 2017

\section{An unusual abdominal wall mass in a child}

\author{
Amalia Maria do Espirito Santo Souza, Tomas Marzagão Barbuto, Flávia \\ Alessandra Freitas, Nathalia Fernandes Vianna, Carla Maria Costa \\ Zanchetta, Silvana Forsait, Claudio Borba, Alessandra Milani Prandini de \\ Azambuja, Lilian Maria Cristofani, Vicente Odone Filho
}

\section{ABSTRACT}

Abdominal tumors are one of the most common types of pediatric cancer. Therefore, they should always be included in the differential diagnosis of abdominal masses. Here, we present the case of a child whose initial hypothesis of diagnosis contemplated this possibility. Later, it was demonstrated that the abdominal mass found was secondary to a common parasitosis. A 2-year old, moderately malnourished and pale white boy was referred with a history of a rapidly growing, well-limited, middle abdominal mass. The mass was 10 by $3 \mathrm{~cm}$, hard and poorly movable, apparently involving both abdominal rectus muscles. A complete resection was performed, revealing an abdominal wall abscess, with intense eosinophilic proliferation, secondary to a local and intense reaction to innumerous Ascaris lumbricoides eggs. Extra luminal infestations with Ascaris, that usually form peritoneal granulomas have been previously described. However, neither external trauma nor fistula, that could explain the superficial presence of the eggs, was found. This description reinforces the relevance of infectious diseases within the differential diagnosis of abdominal masses, particularly in areas with high prevalence of parasitic infestations.

KEYWORDS: Ascaris lumbricoides. Abdominal mass. Abdominal tumor in children.

\section{INTRODUCTION}

Abdominal tumors are a common type of pediatric cancer. They may even be the most prevalent cancer in areas such as Equatorial Africa, where Burkitt lymphomas are predominant (50\% of all kinds of childhood cancers) ${ }^{1}$.

Developing countries still have a high prevalence of helminth infestations in the pediatric age group. Consequently, children are required to take anti-parasitic drugs prior to starting any sort of immunosuppressive treatment, especially chemotherapy ${ }^{2}$.

In this study, we report the unique situation of a child whose presentation of a parasitic disease was an abdominal tumor. This is a provocative report that raises concerns on how frequently common and widely disseminated diseases, such as parasitosis, may be neglected.

\section{CASE REPORT}

This case report contains a retrospective review of the medical records, an extensive literature review and a specific pathophysiological discussion.

OMG, WM, age: 2 years and 10 months, was hospitalized due to progressive abdominal enlargement, noticed during the previous 2 weeks. Mebendazol had 
been administered several times in the past for worm elimination in the stools. The last administration took place approximately four weeks prior to hospitalization and caused elimination of adult forms of Ascaris lumbricoides by vomiting.

Physical examination disclosed an undernourished pale child, with a hard, well-delimited, poorly movable and painless epigastric mass (diameters 3 and $10 \mathrm{~cm}$ ), projecting upon both rectus muscles.

Laboratory analyses had the following results: hemoglobin $5.4 \mathrm{~g} / \mathrm{dL},>1,000,000$ platelets $/ \mathrm{mm}^{3}, 19,600$ leukocytes/ $\mathrm{mm}^{3}$, marked eosinophilia $\left(9,210 / \mathrm{mm}^{3}\right)$.

A stool specimen was collected and concentrated to detect the presence of parasites by microscopic examination. Trichuris trichiura and Ascaris lumbricoides eggs were detected.

The chest X-ray was normal and the abdominal ultrasound showed a hyperechoic mass matching the one that was clinically described.

A complete excision was performed to determine the nature of the abdominal mass. It revealed an abscess in the medial portion of the right rectus muscle, with signs of necrosis and containing a purulent material. Abscess formation was determined by marked granulomatous inflammatory reaction associated with fibroblastic proliferation and with innumerable Ascaris lumbricoides eggs, "foreign bodies" (Figure 1). Ulterior additional imaging search failed to reveal any significant alterations.

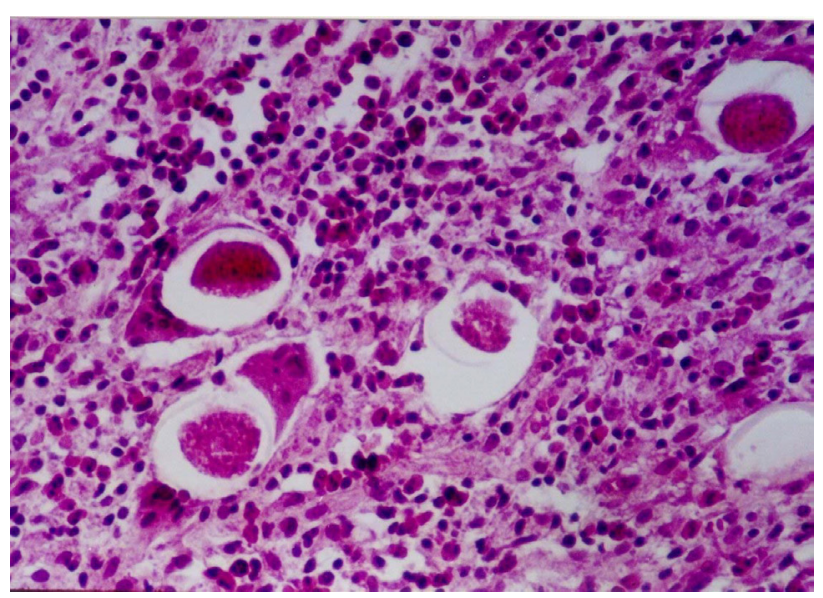

Figure 1 - Abscess formation, secondary to the presence of Ascaris lumbricoides eggs.

\section{DISCUSSION}

Childhood cancer is an uncommon pediatric condition. Nevertheless, it is a possibility that should be considered when analyzing "abdominal masses". The proportion of malignant diseases diagnosed upon the detection of an abdominal mass increases with age (Table 1$)^{3}$. Among infants and children, most malignant tumors have a retroperitoneal origin, neuroblastoma being the most frequent one ${ }^{3}$.

Table 1 - Abdominal masses: malignant $(M) /$ benign $(B)$ diseases according to age

\begin{tabular}{cc}
\hline Neonatal period & Infants and children \\
\hline & Retroperitoneal \\
\hline Renal: $55 \%$ & Renal: $55 \%$ \\
Non-renal: $10 \%$ & Non-renal: $23 \%$ \\
Gastrointestinal: $20 \%$ & Gastrointestinal: $11 \%$ \\
Genital: $15 \%$ & Genital: $4 \%$ \\
\hline Total: $\mathbf{M}$ / B: $\mathbf{1 5 \% / 8 5 \%}$ & Retroperitoneal: $\mathbf{M}$ / B: $\mathbf{4 3 \% / 3 5 \%}$ \\
\hline
\end{tabular}

A few small series ${ }^{4}$ reports and scattered reports ${ }^{5}$ on abdominal wall masses reveal a preponderance of benign conditions, mostly of infectious origin, and of hematomas (Table 2).

Table 2 - Abdominal wall masses in children

\begin{tabular}{lcc}
\hline Age (years) & Location & Diagnosis \\
\hline $11 \frac{1}{2}$ & RAW & Hematoma \\
4 & LAW & Abscess \\
3 & RAW & Abscess \\
4 & RAW & Hematoma \\
2 & RAW & Hematoma \\
$1-12$ & LAW & Abscess \\
5 & RAW and chest & Abscess \\
\hline RAW = Right Abdominal Wall/ LAW $=$ Left & Abdominal Wall. \\
Source: Khajavi and Zarabo &
\end{tabular}

Although medical history, physical examination and complete blood count of the patient all supported the diagnosis of a parasitic disease, there were no specific symptoms or signs directly suggesting what was the underlying cause of the abdominal mass. Only mass excision was able to establish the correct diagnosis of foreign body reaction secondary to Ascaris lumbricoides eggs.

Most Ascaris infections occur without any associated clinical repercussions, which are essentially restricted to people with heavy worm loads ${ }^{6}$. Besides jeopardizing the nutritional status of heavily infected individuals (increased protein loss may contribute to protein energy malnutrition ${ }^{7,8}$ and to vitamin $\mathrm{A}$ and $\mathrm{C}$ deficiency ${ }^{8}$ ), several other severe complications may occur (Table 3). Up to 20,000 deaths 
per year, secondary to severe clinical disease caused by Ascaris, were reported during the 1980s ${ }^{9}$.

Table 3 - Frequent events associated with massive Ascaris lumbricoides infestations

\begin{tabular}{cc}
\hline Ascaris pneumonia & Respiratory symptoms \\
\hline Intestinal Ascaris & Obstruction \\
& Peritoneal ascariasis \\
& Appendicular ascariasis \\
& Hepatobiliary ascariasis \\
& Pancreatic ascariasis \\
\hline
\end{tabular}

Source: Khuroo $^{5}$

The presence of Ascaris sp. forms outside the bowel depends on pulmonary larval migration, perforations and reactions against Ascaris sp. products that lead to granuloma formation. During larval migration, dead larvae present in the hepatic sinusoids may promote the formation of granulomas $^{5,10-17}$.

However, the development of tumors outside the gastrointestinal tract is quite uncommon ${ }^{18-35}$, occurring mostly in the peritoneum ${ }^{18-23,25-31,35}$.

Ascaris may enter the peritoneal cavity either through a gangrenous bowel or through perforation ${ }^{5}$. However, the presence of worms in the peritoneum with an intact bowel is well established ${ }^{5,21}$. This condition is associated with high mortality ${ }^{23}$. When the patients survive, the disintegrated worm and its ova ${ }^{5}$ elicit a granulomatous reaction, explaining the formation of a pseudo tumor.

Granulomatous reactions secondary to the worms and ova are also seen in areas not directly related to the bowel, such as the kidneys, heart and brain ${ }^{5,32,34}$. Their development, as described in this report, is probably secondary to the worm deposition that may happen during larval migration through both veins and the lymphatic system $^{5,36}$. Due to the widespread distribution of Ascaris, this rarely described benign tumor counterpart of the disease probably has an underestimated frequency.

\section{CONCLUSION}

This unique case report brings to light the need to consider, especially in developing countries, infectious and parasitic diseases in the differential diagnosis of abdominal masses.

Worldwide distribution of Ascaris lumbricoides shows a very significant endemic presence in tropical countries and in areas with poor sanitation, with $8 \%$ of estimated infestations occurring in South America. The most affected age group is 1 to 10 years $^{6}$.

\section{CONFLICT OF INTERESTS}

The authors have no conflicts of interest to disclose.

\section{ACKNOLEGMENTS}

We are indebted to Prof. Vicente Amato Neto and Dr. Jacyr Pasternak for all the comments and suggestions regarding this manuscript.

\section{REFERENCES}

1. Hesseling P, Israels T, Harif M, Chantada G, Molyneux E, FCEM. Practical recommendations for the management of children with endemic Burkitt lymphoma (BL) in a resource limited setting. Pediatr Blood Cancer. 2013;60:357-62.

2. Martinez Péres A, Justiniani Cedeño NE. Incidence of intestinal parasites in pediatric patients with hematologic neoplasms from 1 to 15 years of age. Rev Alerg Mex.1999; 46:26-9.

3. Merten DF, Kirks DR. Diagnostic imaging of pediatric abdominal masses. Pediatr Clin North Am. 1985;32:1397-425.

4. Khajavi A, Zarabo M. Abdominal wall masses in children. Clin Radiol.1972;23:495-9.

5. Khuroo MS. Ascariasis. Gastroenterol Clin North Am. 1996; 25:553-77.

6. Silva AVM, Massara CL. Ascaris lumbricoides. In: Neves DP ed. Parasitologia dinâmica. $3^{\text {rd }}$ ed. São Paulo: Atheneu; 2009. p. 253-60.

7. Symons LEA. Anorexia: occurrence in pathophysiology and possible causes in parasitic infections. Adv Parasitol. 1985; 24:103-33.

8. Thein H, Thane T, Than S, Myat LK, Myint L. A controlled chemotherapeutic intervention trial on the relationship between Ascaris lumbricoides infection and malnutrition in children. Trans R Soc Trop Med Hyg. 1991;85:523-8.

9. Pawlowski ZS, Davies A. Morbidity and mortality in ascariasis. In: Crompton DWT, Nesheim MC, Pawlowski ZS, editors. London: Taylor \& Francis; 1989. p. 45-69.

10. Kakihara D, Yoshimitsu K, Ishigami K, Irie H, Aibe H, Tajima $\mathrm{T}$, et al. Liver lesions of visceral larva migrans due to Ascaris suum infection: CT findings. Abdom Imaging. 2004; 29:598602.

11. Fogaça HS, Oliveira CS, Barbosa HT, Lanfredi RM, Chagas V. Liver pseudotumor: a rare manifestation of hepatic granulomata caused by Ascaris lumbricoides ova. Am J Gastroenterol. 2000; 95:2099-101.

12. Pereira FE, Musso C, Castelo JS. Pathology of pyogenic liver abscess in children. Pediatr Dev Pathol. 1999; 2:537-43.

13. Ferreira MA, Pereira FE, Musso C, Dettogni RV. Pyogenic liver abscess in children: some observations in the Espírito Santo State, Brazil. Arq Gastroenterol. 1997;34:49-54. 
14. Seitz HM. Parasitic diseases of the liver. Verh Dtsch Ges Pathol 1995;79:241-8.

15. Pelissier E, Quilici M, Marquet G, Pages C. Hepatic Ascaris granuloma. Chirurgie. 1977;103:343-7.

16. Kuster G, Oyarce R, Boero D. Hepatic granuloma by Ascaris lumbricoides eggs. Bol Chil Parasitol. 1966;21:48-50.

17. Khaleque KA, Alam KS. Hepatic granuloma caused by Ascaris ova. J Trop Med Hyg. 1963; 66:249-51.

18. Lacaz CS, Pettinati AH, Paula AB, Souza D, Zandin R. Granuloma solitário por Ascaris lumbricoides de localização intraperitoneal simulando coccidioidomicose. Rev Inst Med Trop Sao Paulo. 1982; 24:378-84.

19. Shin MH, Lee YA, Min DY. Eosinophil-mediated tissue inflammatory responses in helminth infection. Korean $\mathrm{J}$ Parasitol. 2009;47:125-31.

20. Gahukamble DB, Gahukamble L. Granulomatous peritonitis due to Ascaris lumbricoides. Ann Trop Paediatr. 1987;7:142-4.

21. Aldemir M, Yilmaz G, Girgin S, Akgün Y. Granulomatous peritonitis due to Ascaris lumbricoides. Ulus Travma Derg. 2000; 6:296-8.

22. Kinde-Gazard D, Gangbo F, Anagonou S, Gninafon M, Massougbodji A. Granulomatous peritonitis from ascariasis: apropos of 1 case in a Benin child. Bull Soc Pathol Exot. 2000; 93:23-4.

23. Chen D, Bo L. Ascaris peritonitis and peritoneal granuloma in China. J Gastroenterol. 1997; 32: 826-9.

24. Adebamowo CA, Akang EE, Ladipo JK, Ajao OG. Ascarid granuloma presenting as pseudotumour. Trop Geogr Med. 1993; 45:86-8.

25. Mello CM, Briggs MC, Venâncio ES, Brandão AB, Queiroz Filho CC. Granulomatous peritonitis by Ascaris. J Pediatr Surg. 1992; 27:1229-30.
26. Walter N, Krishnaswami H. Granulomatous peritonitis caused by Ascaris eggs: a report of three cases. J Trop Med Hyg. 1989; 92: 17-19.

27. de Icaza MM, Johnson CM. A case of granulomatous peritonitis caused by Ascaris lumbricoides ova. Rev Med Panama. 1981; 6:160-3.

28. Formiga Ramos CC, Oliveira Ramos AM, Carvalho AR. Pseudotumorous form of ascariasis. Report of a case. Am J Trop Med Hyg. 1980; 29:795-8.

29. Grozdev LJ, Vlaska R, Kirkov LJ, Petrov N. A case of granulomatous peritonitis caused by Ascaris lumbricoides and its eggs. Acta Chir Iugosl. 1979;26:67-77.

30. Paul M, Dissanaike AS. Solitary intraperitoneal granuloma caused by Ascaris lumbricoides. Ceylon Med J. 1977; 22:171-8.

31. Reddy CR, Venkateswar Rao D, Sarma EN, Swamy GM. Granulomatous peritonitis due to Ascaris lumbricoides and its ova. $1975 ; 78: 146-9$.

32. Dutt AK, Beasley D, Sandosham AA. Eosinophilic granuloma of pancreas caused by Ascaris eggs. Med J Malaya. 1969; 24:158-60.

33. Mylvaganam C, Panabokke RG. Extra-intestinal Ascaris granuloma. J Trop Med Hyg. 1969;72:98-100.

34. Baar HS, Galindo J. Ossifying pulmonary granulomatosis due to larvae of Ascaris. J Clin Pathol. 1965; 18:737-42.

35. Aballi AJ, Villa Campos J, Torroella E Jr, Marin Cuetara R, Garcia Palacio A. Granuloma parasite Ascaris lumbricoides intraperitoneal. Rev Cubana Pediatr. 1956; 28: 143-50.

36. Rathmell TK, Mora JJ, Volodkevich P. Visceral granulomas caused by migrating larvae of Ascaris lumbricoides. Am J Clin Pathol.1954; 24:445-7. 